\title{
Morphological Variation of Gephyrocapsa oceanica Kamptner 1943 in Plankton Samples: Implications for Ecologic and Taxonomic Interpretations
}

\author{
Jörg Bollmann ${ }^{a, c, 1}$, and Christine Klaas ${ }^{b, c}$ \\ ${ }^{a}$ Department of Geology, Earth Sciences Centre, University of Toronto, 22 Russell Street, Toronto, Ontario, \\ Canada M5S 3B1 \\ ${ }^{\mathrm{b}}$ Alfred Wegener Institute for Polar and Marine Research, Am Handelshafen 12, \\ 27570 Bremerhaven, Germany \\ 'Earth Science Department ETH Zürich, Sonneggstrasse 5, CH-8092 Zürich, Switzerland
}

Submitted September 7, 2007; Accepted February 9, 2008

Monitoring Editor: Michael Melkonian

Morphological analysis of Gephyrocapsa spp. in plankton samples confirms the existence of five out of six morphotypes that were previously reported from Holocene sediments. Our data suggest a much higher diversity within the genus Gephyrocapsa than the currently accepted species circumscriptions. Furthermore, we confirm the morphological species delineations made by Kamptner that allow the separation of three morphological groups within the genus Gephyrocapsa: one group with large bridge angles (G. oceanica var. typica Kamptner 1943), a second group with small bridge angles (G. oceanica var. californiensis Kamptner 1956) and a third group of small coccoliths (G. aperta Kamptner 1963). However, a seemingly continuous transition from small to large coccoliths within G. oceanica var. typica along a temperature gradient points either to a high phenotypic plasticity of G. oceanica var. typica or numerous sibling species highly adapted to specific environmental conditions. Testing of these hypotheses is of utmost importance to understanding the diversity of marine plankton and its evolution, and to assessing the impact of future and past environmental change on primary producers such as coccolithophorids.

(c) 2008 Elsevier GmbH. All rights reserved.

Key words: prymnesiophyte; coccolithophorids; morphospecies; phenotypic plasticity; marine protest; biodiversity.

\section{Introduction}

The oceans cover about $71 \%$ of the Earth's surface and thus marine micro-organisms may play a major role in shaping the global environment. Coccolithophores represent a particularly

\footnotetext{
Corresponding author; fax +14169783938

e-mail bollmann@geology.utoronto.ca (J. Bollmann).
}

important group of marine micro-organisms because they constitute a significant part of the marine food web as primary producers and are important players in global biogeochemical cycles. Their production of dimethyl sulphide (DMS) and of calcite platelets, respectively, might have had a major impact on the global climate 
since their first occurrence in the late Triassic (Westbroek et al. 1993). Therefore, knowledge of the factors driving their distribution in today's ocean is essential to assessing the impact of future and past environmental change on the marine ecosystem and on marine plankton evolution. However, the biodiversity, biogeography, ecology and evolution of coccolithophores are still not well understood (Thierstein and Young 2004). One reason for our lack of understanding appears to be the morphology-based taxonomic species concept that currently does not account for small-scale morphological variability possibly reflecting species-level biodiversity.

The traditional taxonomic perception of homogeneous cosmopolitan species has become questionable in recent years because several cosmopolitan species exhibit remarkable fine scale morphological variations (Bollmann 1997; Bollmann and Herrle 2007; Hagino et al. 2000; Knappertsbusch et al. 1997; Quinn et al. 2005; Young and Westbroek 1991). These fine scale variations allow the identification of morphotypes that show a characteristic biogeographic pattern or environmental adaptation (Brand 1981). These results have led to questions regarding whether eco-phenotypic or genotypic variation within the cosmopolitan species such as Gephyrocapsa oceanica cause the fine scale morphological variation (Bollmann 1997).

\section{Species Definitions within the Genus Gephyrocapsa}

All extant species of the genus Gephyrocapsa form spherical to sub-spherical coccospheres of elliptical coccoliths with a diagonal bridge crossing the central area of the coccoliths (Kamptner 1943). Many variations of coccolith size, coccolith bridge angle and shape, the central collar, and the size of the central pore exist. In his original definition of the genus Gephyrocapsa, Kamptner (1943) included all coccoliths with a single bar (bridge) across the central area. Kamptner (1956) first used the angle between the bar crossing the central area and the short axis of the elliptical central area (bridge angle) to distinguish between G. oceanica var. typica Kamptner, 1943 (large bridge angle) and $G$. oceanica var. californiensis Kamptner, 1956 (small bridge angle), and the coccolith size to identify G. aperta Kamptner, 1963 (small size: $2-3 \mu \mathrm{m}$ ).

Mclntyre et al. (1970) used similar morphological characteristics, but provided for the first time precise morphometric boundaries to distinguish species within Gephyrocapsa. Mclntyre et al. (1970) distinguished three species: G. oceanica (warm water species with a bridge angle greater than $45^{\circ}$ ), G. caribbeanica Boudreaux and Hay, 1967 (cold water species with a bridge angle smaller than $\left.45^{\circ}\right)$ and the small $(2.2-1.9 \mu \mathrm{m}) \mathrm{G}$. ericsonii Mclntyre and Bé, 1967. Later, PujosLamy (1976), Bréhéret (1978) and Samtleben (1980) distinguished several morphotypes whithin the genus Gephyrocapsa based on measurements of size and bridge angle of Gephyrocapsa coccolith assemblages from sediment samples. Since then, various combinations of size, bridge angle, roundness (ratio of width/length), pore width and other descriptive features led to the description of numerous morphospecies from the Miocene to the Holocene. A detailed overview is given by Perch-Nielsen (1985) and Bollmann (1997; Table 1).

Currently, the extant Gephyrocapsa species delineations used closely resemble those proposed by Kamptner $(1956,1963)$ based on bridge angle and coccolith size: G. oceanica var. typica (large bridge angle), G. oceanica var. californiensis (syn. G. muellerae Bréhéret, 1978; syn. G. caribbeanica Boudreaux and Hay, 1967; small bridge angle) and G. aperta (syn. G. ericsonii Mclntyre and Bé, 1967; distinguishable by its minute coccoliths). An additional distinction of Gephyrocapsa species with small coccolith size has been used based on ornamentations of the central collar or the shape of the distal shield (i.e. Gephyrocapsa ornata Heimdall, 1973; Gephyrocapsa crassipons Okada and Mclntyre, 1977; Gephyrocapsa protohuxleyi McIntyre, 1970). In contrast to previous studies, the quantitative morphological analysis of Gephyrocapsa assemblages from globally distributed Holocene sediment samples revealed six dominant morphological associations related to distinct environmental conditions with respect to sea surface temperature and productivity (Figure 1; Bollmann (1997)). Furthermore, morphological parameters such as size or bridge angle appear to vary with environmental conditions such as temperature, showing seemingly continuous transitions between all morphological associations, suggestive of one global species with high eco-phenotypic plasticity (Fig. 1).

Bollmann (1997) described the different morphotypes informally because it is not evident from his sediment analysis whether the different morphotypes correspond to discrete species, or to one species showing a high phenotypic plasticity. 


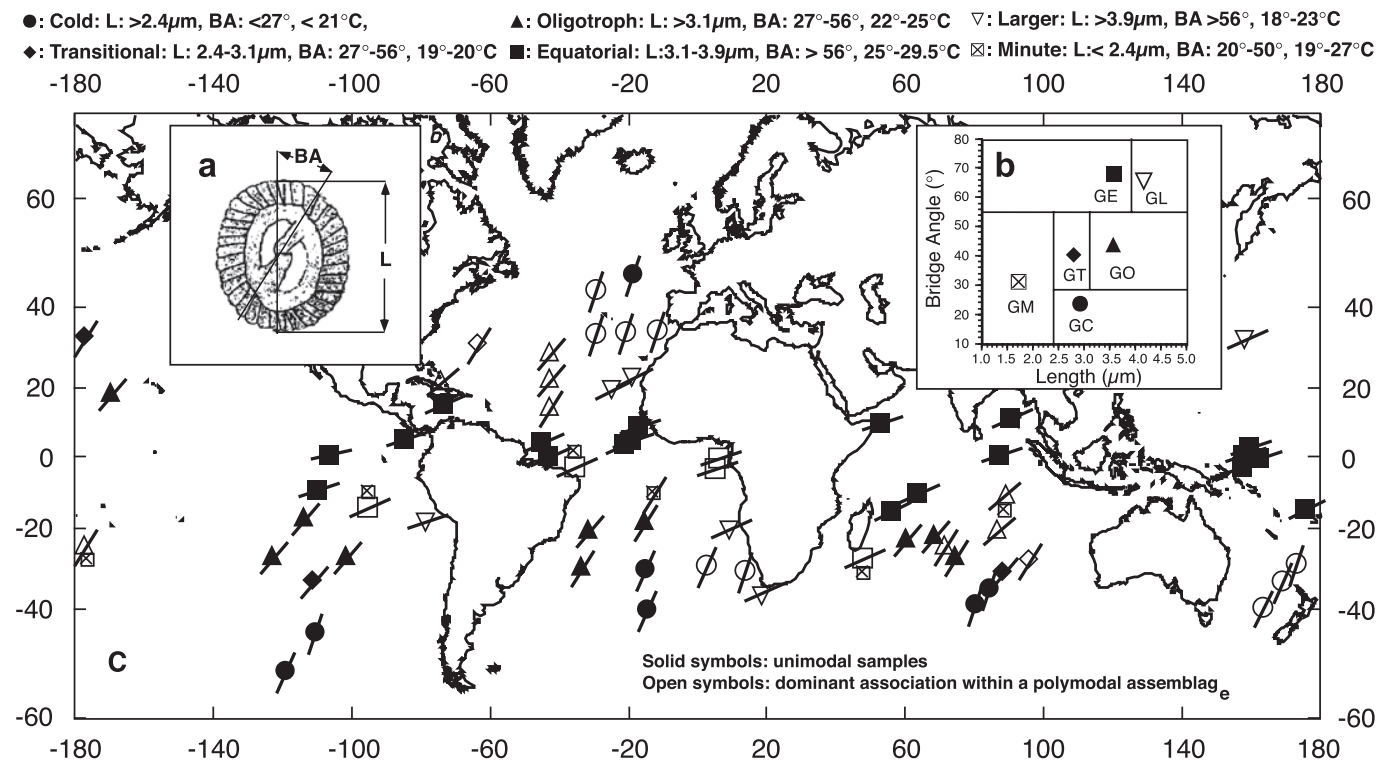

Figure 1. Morphological variation of Gephyrocapsa in Holocene sediments. (A) Morphological measurements determined from a single coccolith: BA, Bridge angle; L, Coccolith Length. (B) Six morphological associations of Gephyrocapsa determined in Holocene sediment assemblages. (C) Biogeography of the six different Gephyrocapsa morphological associations determined in Holocene sediments. The lines over the symbols indicate the mean orientation of the bridge within an assemblage (modified after Bollmann (1997)).

Furthermore, taxonomic and ecological data inferred from sediment samples might be biased by taphonomic effects such as selective dissolution of morphotypes, lateral transport, sediment mixing via bioturbation, or seasonal variations in the production of different morphotypes.

Several feasiblility tests need to be conducted to verify whether the different Holocene morphotypes represent distinct species (Bollmann 1997). These tests include the following: (1) Studies of plankton and trap materials from time-series stations would reveal whether the Holocene morphotypes and morphological associations are present in the plankton, and might indicate whether morphological changes in coccoliths on living coccospheres along an environmental gradient are continuous (suggestive of phenotypic variation) or discontinuous (suggestive of successions of genetically distinct populations). (2) Culture experiments of monoclonal populations of Gephyrocapsa isolates from various regions grown under various environmental conditions would provide a test for phenotypic plasticity. A change in morphology of any cultured population into that of another morphotype would provide positive evidence for phenotypic plasticity. Consequently, populations of these different morphotypes would assume the taxonomic rank of subspecies. (3) Finally, genetic and morpho- metric analysis of Gephyrocapsa from cultured strains and in the field (Iglesias-Rodríguez et al. 2006; Saez et al. 2003) are needed.

Here, we analysed the morphology of Gephyrocapsa spp. in plankton samples from all ocean basins covering a range of temperature and productivity gradients (Fig. 2, Table 1), to test whether (1) Holocene morphological associations and morphotypes of the genus Gephyrocapsa can be also identified in the plankton, and (2) different morphotypes represent discrete species or one species showing high eco-phenotypic plasticity.

\section{Results and Discussion}

We analysed the morphology of about 500 coccoliths from 16 globally distributed plankton samples (Figs 3 and 4) and applied the same criteria as Bollmann (1997) to distinguish between unimodal and bi- or polymodal samples and to identify different morphotypes. Our analysis revealed that four of the six Holocene morphotypes reported by Bollmann (1997) were present in unimodally distributed plankton samples (Figs $3 A-F, M$; $4 A-F, M$, and 5A, B). These morphotypes are Gephyrocapsa Equatorial, Gephyrocapsa Larger, Gephyrocapsa Cold, and Gephyrocapsa Minute. The morphotype Gephyrocapsa Transitional (GT) 


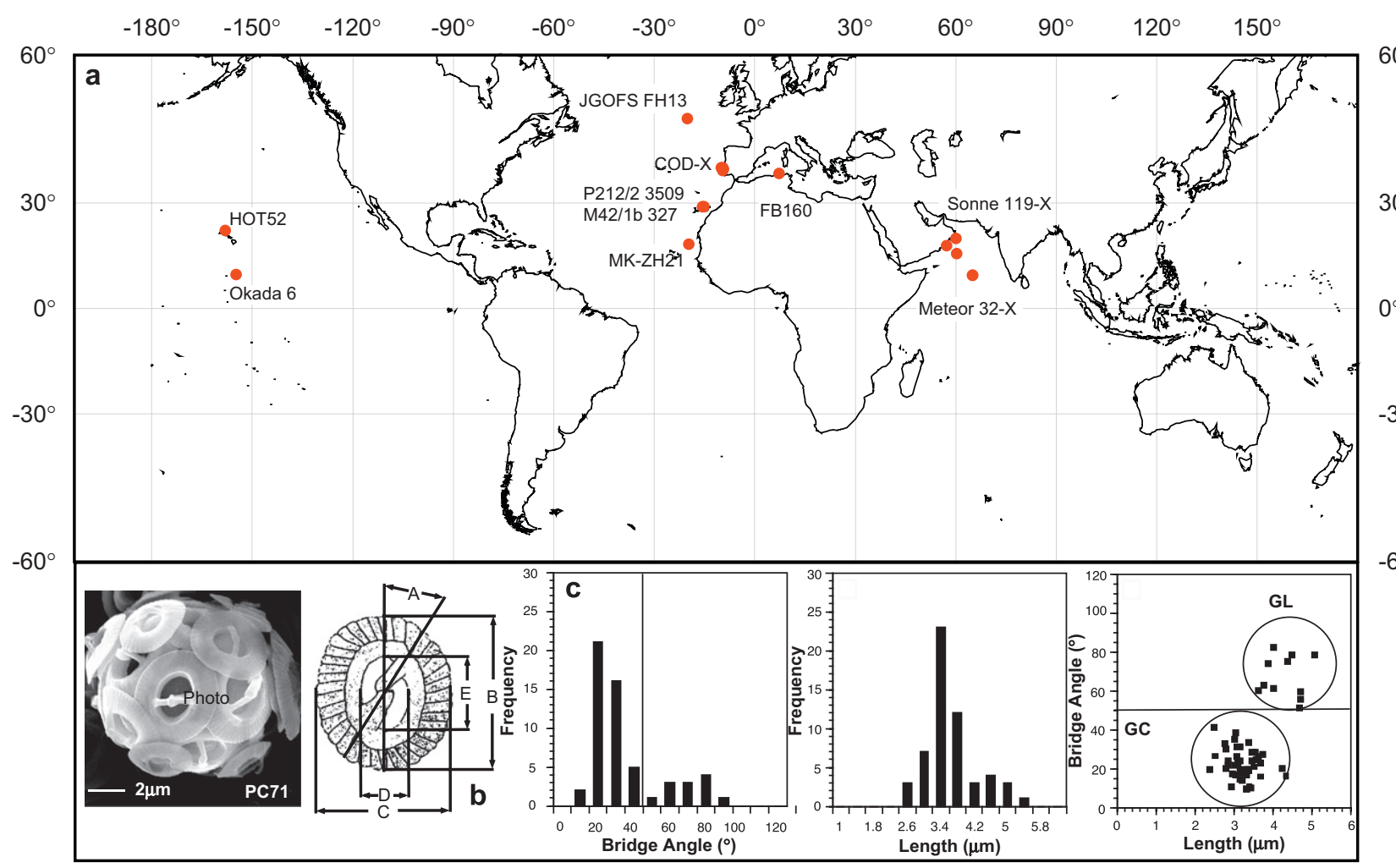

Figure 2. (A) Locations and code names of sampling sites for plankton samples analysed in this study; names with an X represent locations where various samples were taken (Table 1). (B) Left panel: SEM picture of a coccosphere of Gephyrocapsa oceanica. Right panel: dimensions measured from digitised SEM pictures of a single coccolith; bridge angle measured from the long axis of the central area (a), coccolilth length (b), coccolith width (c), length of the central area (d), width of the central area (e). (C) Example of a bimodal assemblage consisting of two morphological associations. Left panel: frequency distribution of the bridge angle (interval size $10^{\circ}$ ). Middle panel: frequency distribution of the length (interval size $0.4 \mu \mathrm{m}$ ). Right panel: scatter plot of length versus bridge angle showing separation of the assemblage into two distinct morphological associations Gephyrocapsa Cold (GC) and Gephyrocapsa Larger (GL). The standard deviation of the assemblage is $19.91^{\circ}$ for the bridge angle and $0.59 \mu \mathrm{m}$ for length. After separating the two modes, the standard deviations of the dominant mode $(\mathrm{GC})$ is $7.5^{\circ}$ for the bridge angle and $0.39 \mu \mathrm{m}$ for length.

could be identified only in one bimodal sample (Figs 3P, 4P, 5C) and the morphotype Gephyrocapsa Oligotrophic (GO) could not be identified in any plankton sample, although coccolith measurements on single coccospheres corresponded to this morphotype in several of our samples (Fig. 3). The near-absence of Gephyrocapsa Transitional and Gephyrocapsa Oligotrophic in the plankton samples is possibly due to the poor geographical coverage of our samples in the open ocean in general and in the oligotrophic gyres in particular. Hence, the existence of these morphotypes in the plankton cannot be ruled out.

The most common combination of morphotypes in polymodal samples was Gephyrocapsa Larger and Gephyrocapsa Cold (Fig. 3K, L, N, O and P), and to a lesser extent, Gephyrocapsa Minute
(Fig. $3 \mathrm{H}, \mathrm{K}$ and $\mathrm{O}$ ). A similar combination of morphotypes was found in Holocene sediment samples (Bollmann 1997). The co-occurrence of the morphotypes Gephyrocapsa Larger, Gephyrocapsa Cold and Gephyrocapsa Minute in the same plankton sample rules out the presence of one single cosmopolitan species with high phenotypic plasticity dependent on environmental conditions. Furthermore, this observation suggests that each of these morphotypes represents a separate biological species. Therefore, our data support the species delineation of Kamptner (1943, 1956, 1963), who distinguished between $G$. oceanica var. typica (large bridge angle) and $G$. oceanica var. californiensis (small bridge angle) as well as $G$. aperta (small size: $2-3 \mu \mathrm{m})$. 


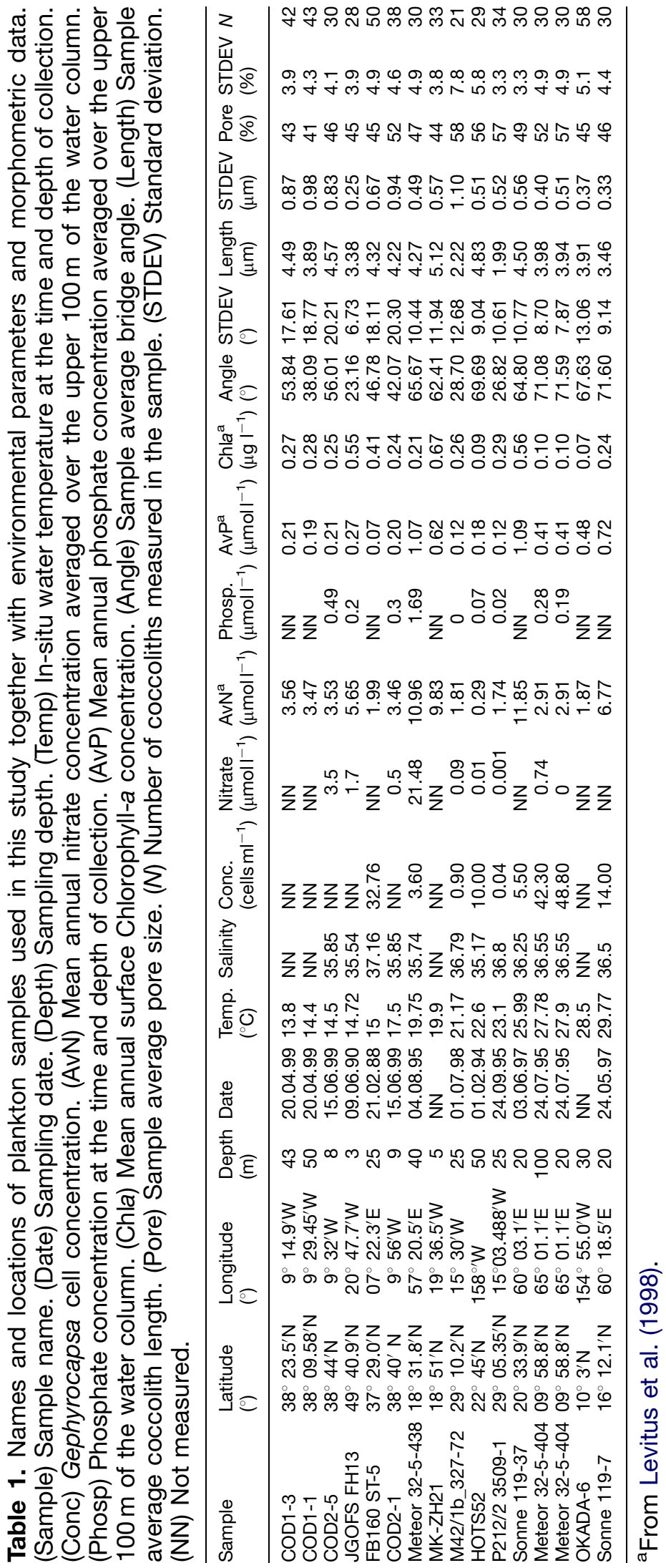



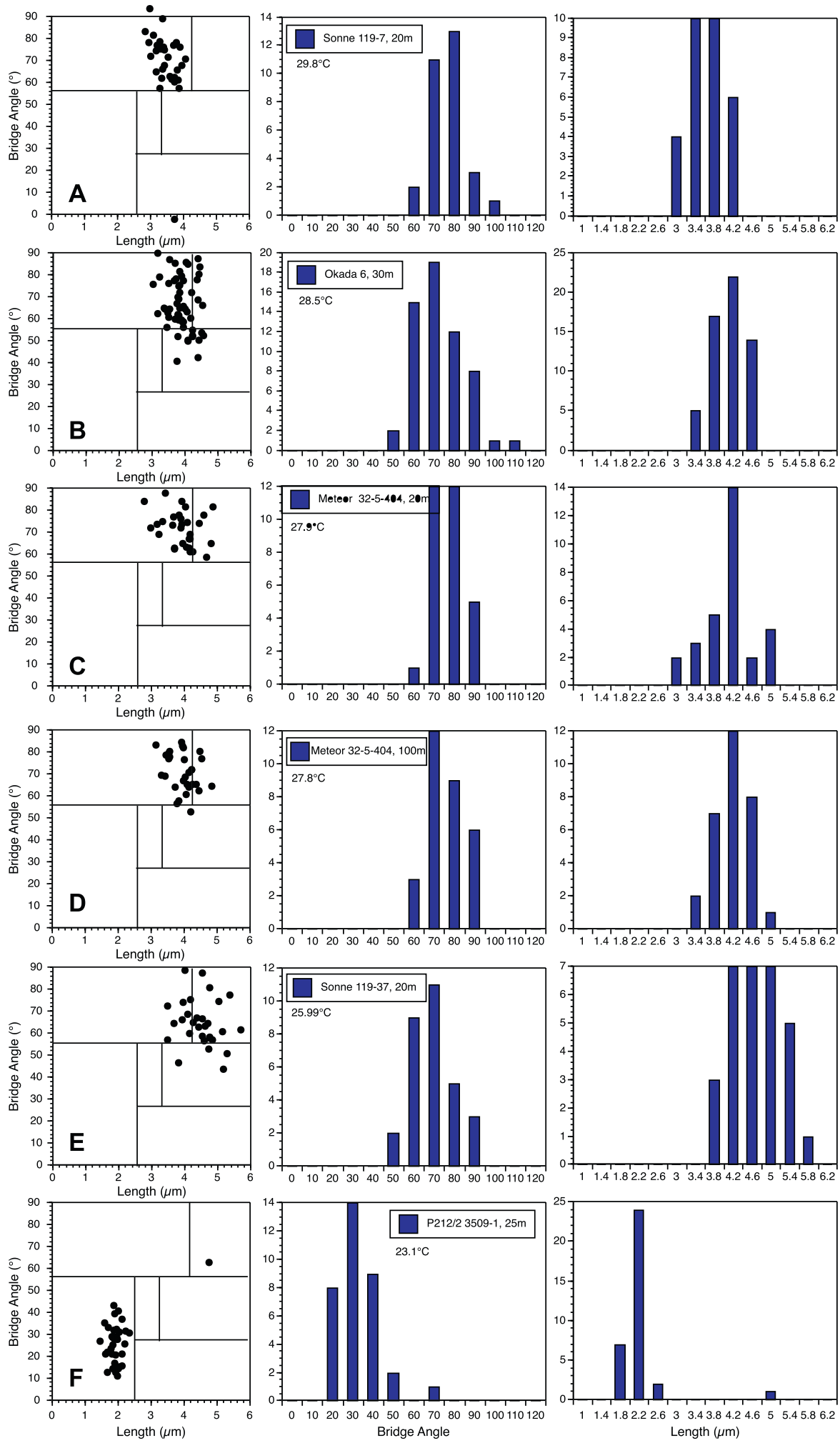

Figure 3. 

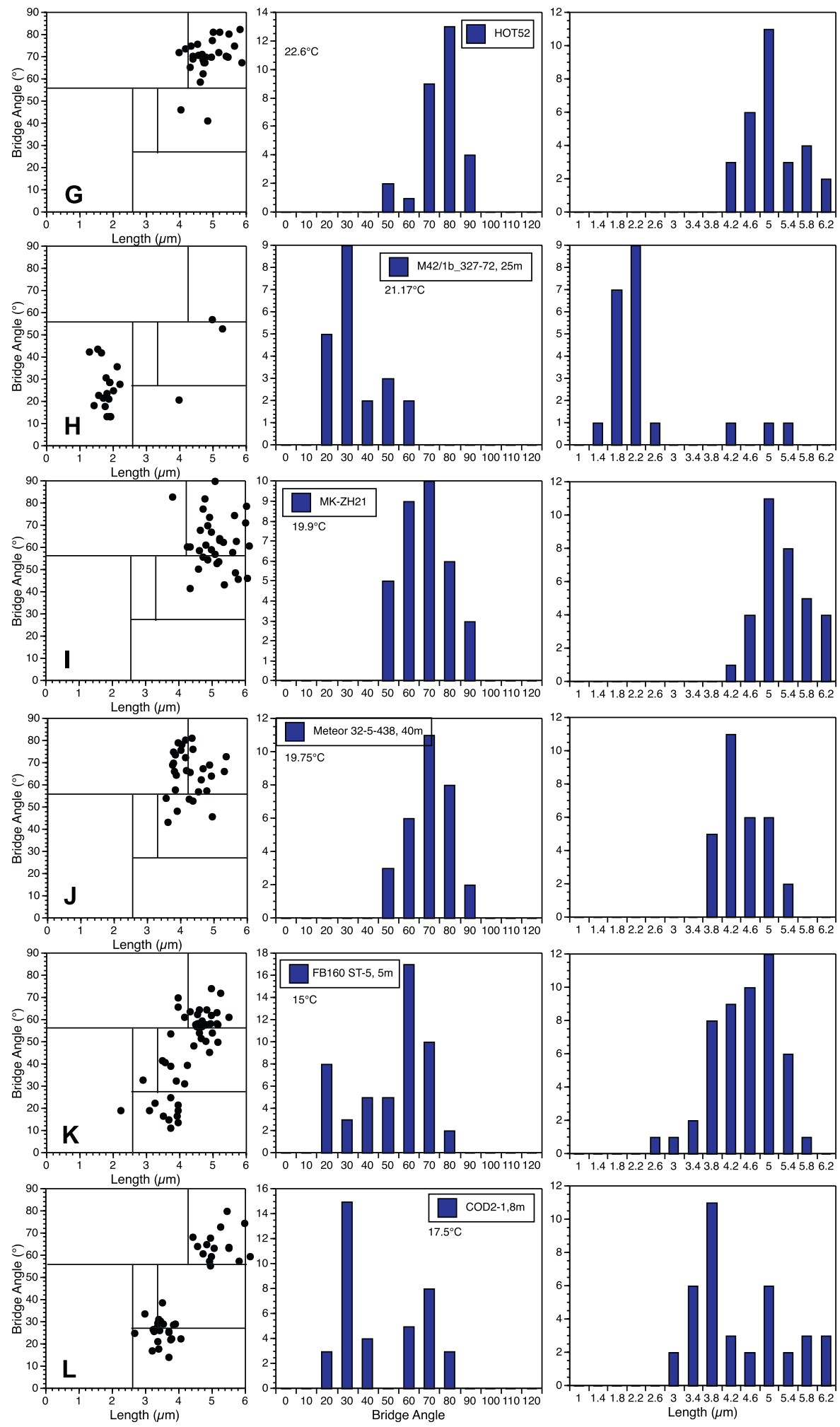

Figure 3. (Continued) 

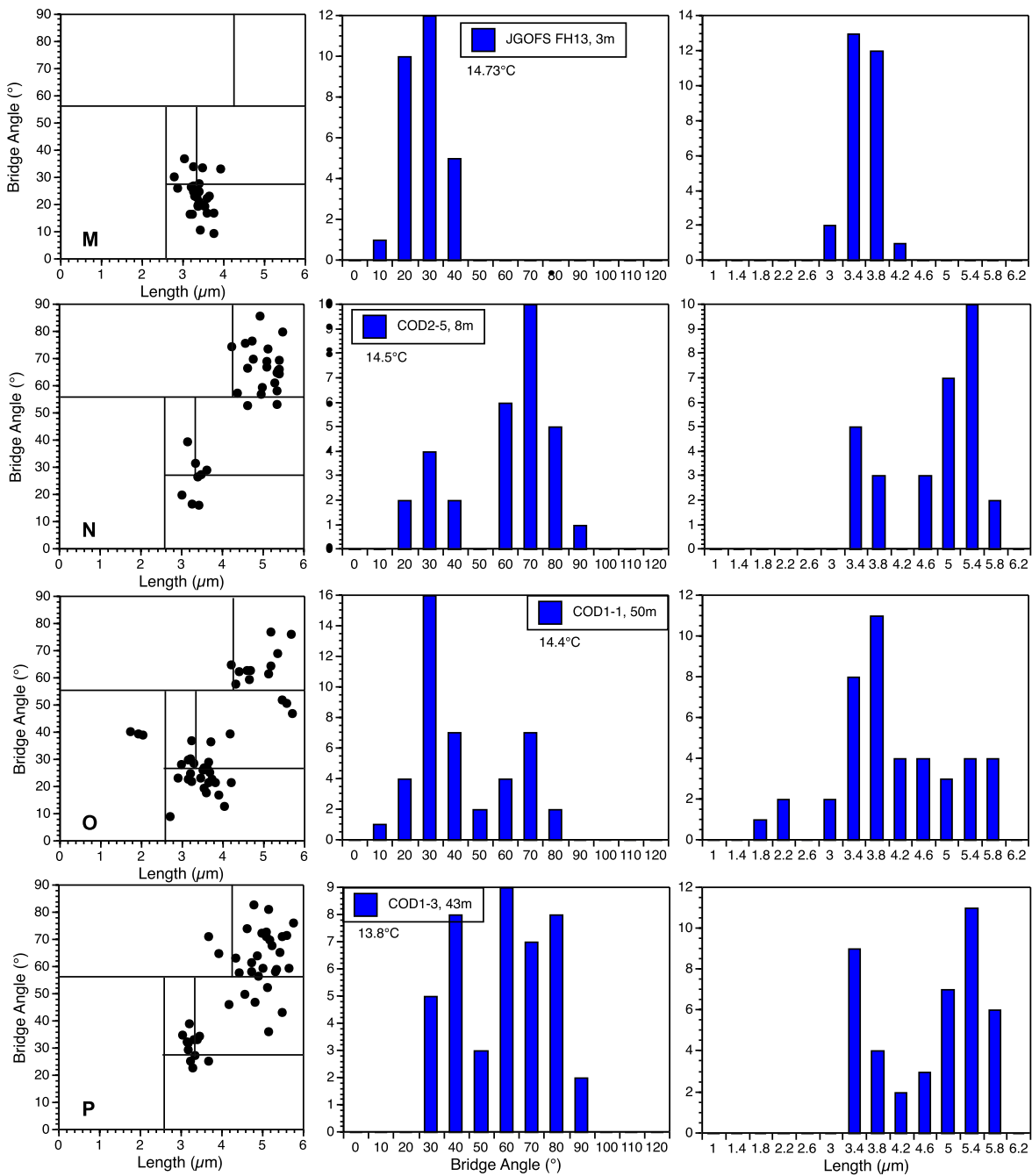

Figure 3. Bivariate plots (left panels) and frequency histograms of coccolith length (middle panels) and bridge angle (right panels) of coccoliths measured during this study in individual plankton samples (A-P). Sample name and temperature at the time of collection are given for each sample in the middle panel. Lines in the bivariate plots indicate morphological boundaries reported by Bollmann (1997).

The seemingly continuous change in morpholocical charateristics along a temperature gradient as reported from Holocene sediments (Bollmann 1997) was observed in the coccolith size of plankton samples (Fig. 5D) but not in the bridge angle. This is a reflection of the fact that only one GT assemblage and no clearly defined GO assemblages were found in plankton samples. However, in contrast to observations from Holocene sediments, the variation in coccolith length with temperature (or other associated environmental variables) is due to a continuous transition between morphotypes with a large bridge angle (Gephyrocapsa Larger and Gephyrocapsa Equator- ial; Fig. 5B, D). Coccolith length of Gephyrocapsa Larger/Gephyrocapsa Equatorial assemblages increase with decreasing temperature, reaching maximum values at $20^{\circ} \mathrm{C}$. Below $20^{\circ} \mathrm{C}$ no change in average coccolith length is observed (Fig. 5D). This can be explained by: (a) mixing between the two morphotypes Gephyrocapsa Larger and Gephyrocapsa Equatorial along the temperature gradient from 20 to $29.6^{\circ} \mathrm{C}$, where Gephyrocapsa Larger represents the "Cold" end member and Gephyrocapsa Equatorial the "Warm" end member; (b) the presence of numerous species highly adapted to a specific temperature; or (c) the presence of phenotypic plasticity within a single 

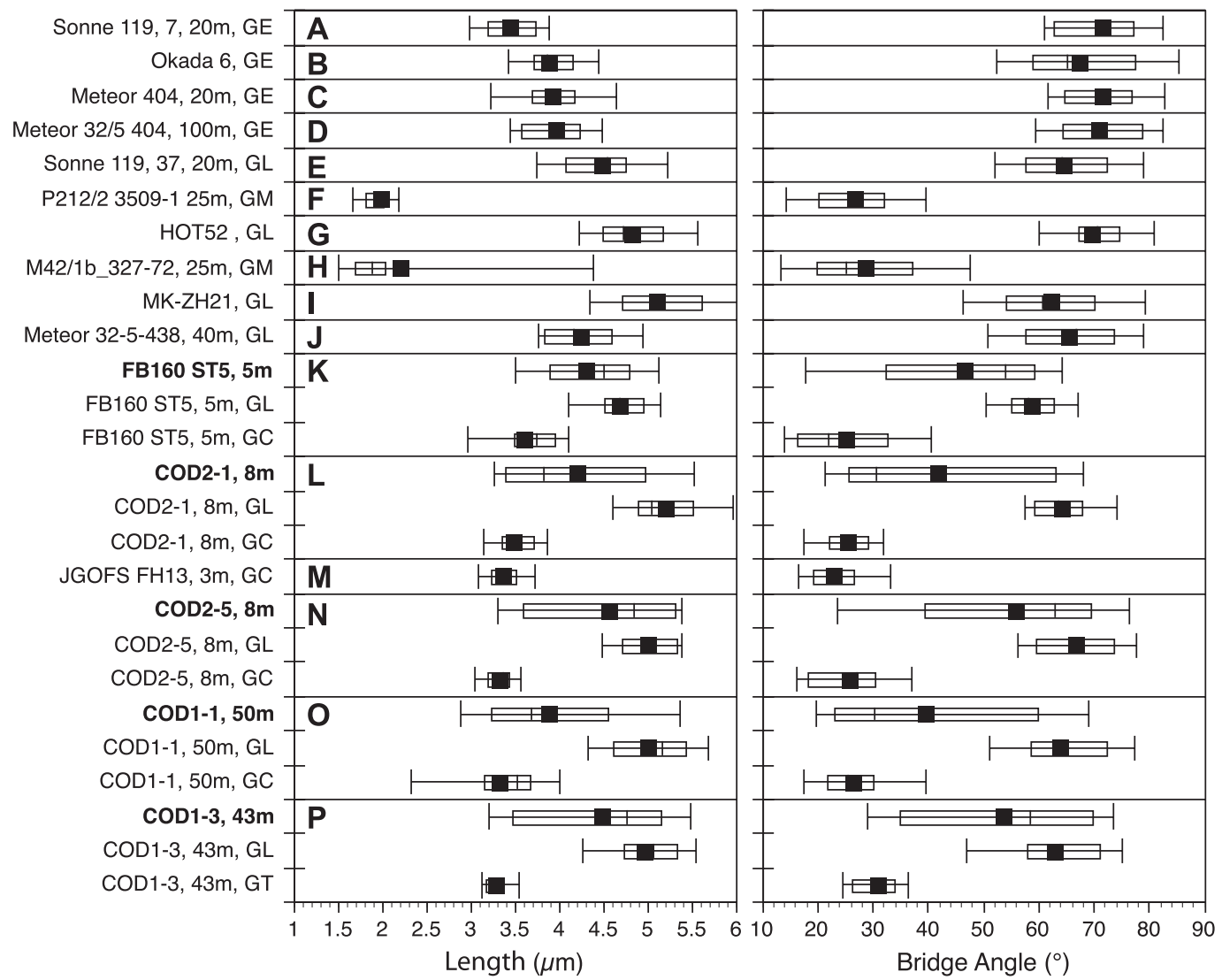

Figure 4. Box plots of plankton samples analysed in this study. Error bars represent the range between smallest and largest value of corresponding morphological parameter in each sample. Lower quartile (lower boundary of open rectangle), median (line inside open rectangle), upper quartile (upper boundary of open rectangle) and average (solid squares) are shown. Note - Sample names in bold indicate bimodal or polymodal samples. In addition, plots of each morphological association of the bimodal or polymodal samples are shown. The separation of morphotypes within polymodal/bimodal assemblages is done based on the bivariate plots. $\mathrm{GE}=$ Gephyrocapsa Equatorial, $\mathrm{GO}=$ Gephyrocapsa Oligotrophic, GT = Gephyrocapsa Transitional, GC = Gephyrocapsa Cold, GL = Gephyrocapsa Larger, GM = Gephyrocapsa Minute.

species in response to changes in temperature or co-varying environmental parameters.

The assumption of a single species is contradicted by the variability in growth rates of various strains of $G$. oceanica determined by Brand (1982) in culture experiments. Additional evidence for the presence of more than one species within Gephyrocapsa oceanica was reported by Hagino et al. (2000). Based on the proportion of the central area as compared to total coccolith area, Hagino et al. (2000) differentiated between two different morphotypes of Gephyrocapsa oceanica with morphotype 1 restricted to eutrophic areas and/or deeper layers in the water column and morphotype 2 occuring in oligotrophic regions. Although information on in-situ nutrient concentrations and primary productivity were not available for several sampling sites in this study, our data essentially confirm the finding of Hagino et al. (2000) as G. oceanica coccoliths with a large central area seem to occur exclusively in areas with high SST $\left(>20^{\circ} \mathrm{C}\right)$, low nutrient concentrations, and low Chlorophyll-a concentration (Figs 5E, 6). Based on the available data, however, we cannot rule out that the transition from a large to a small proportion of the central area is due to ecophenotypic response to environmental conditions.

\section{Ecological Range}

The morphotypic composition of the plankton samples indicates that the patterns observed in Holocene sediment samples are not obscured or 

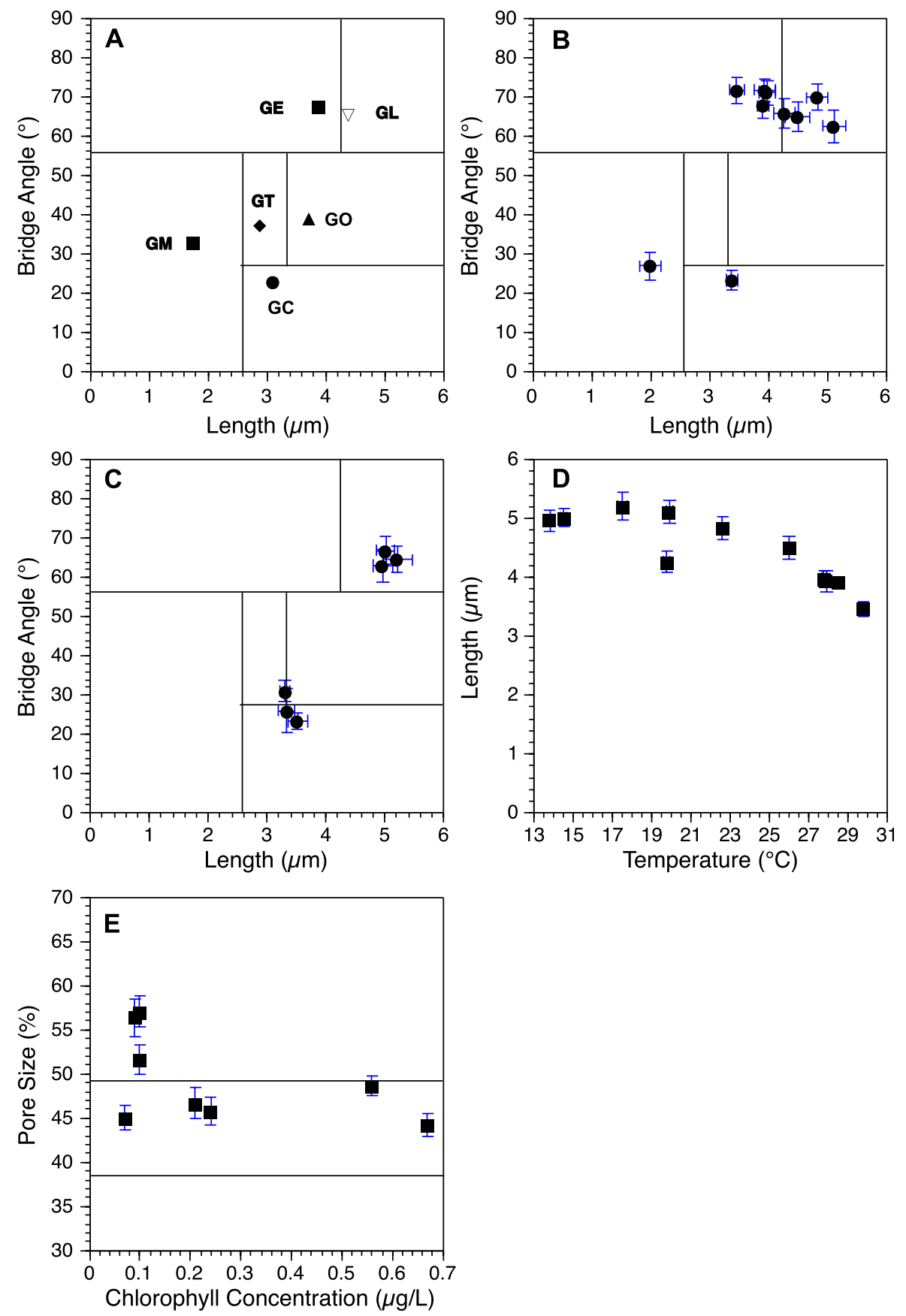

Figure 5. (A) Scatter plots of mean length versus mean bridge angle of morphotypes defined in Holocene sediment samples. Gephyrocapsa Equatorial (GE): mean bridge angle larger than $56^{\circ}$ and mean length between 3.1 and $3.9 \mu \mathrm{m}$. Gephyrocapsa Oligotrophic (GO): mean bridge angle between $27^{\circ}$ and $56^{\circ}$ and mean length larger than 3.1 $\mu \mathrm{m}$ (characteristics of the subtropical central gyres). Gephyrocapsa Transitional (GT): mean bridge angle between $27^{\circ}$ and $56^{\circ}$ and mean length between 2.4 and $3.1 \mu \mathrm{m}$. Gephyrocapsa Cold (GC): mean bridge angle less than $27^{\circ}$ and mean length larger than $2.4 \mu \mathrm{m}$. Gephyrocapsa Larger (GL): mean bridge angle larger than $56^{\circ}$ and mean length larger than $3.9 \mu \mathrm{m}$. Gephyrocapsa Minute (GM): mean bridge angle between $20^{\circ}$ and $50^{\circ}$ and mean length less than $2.4 \mu \mathrm{m}$. (B) Mean bridge angle versus mean length of all unimodal plankton populations. (C) Mean bridge angle versus mean length of morphotypes within the polymodal plankton populations. (D) Mean length of all Gephyrocapsa Larger and Gephyrocapsa Equatorial morphotypes in plankton samples versus in situ temperature. (E) Mean relative pore size versus annual mean chlorophyll concentration. Lines indicate the mean values reported by Hagino et al. (2000). Note - B-E: error bars $=95 \%$ confidence limit of the mean. 

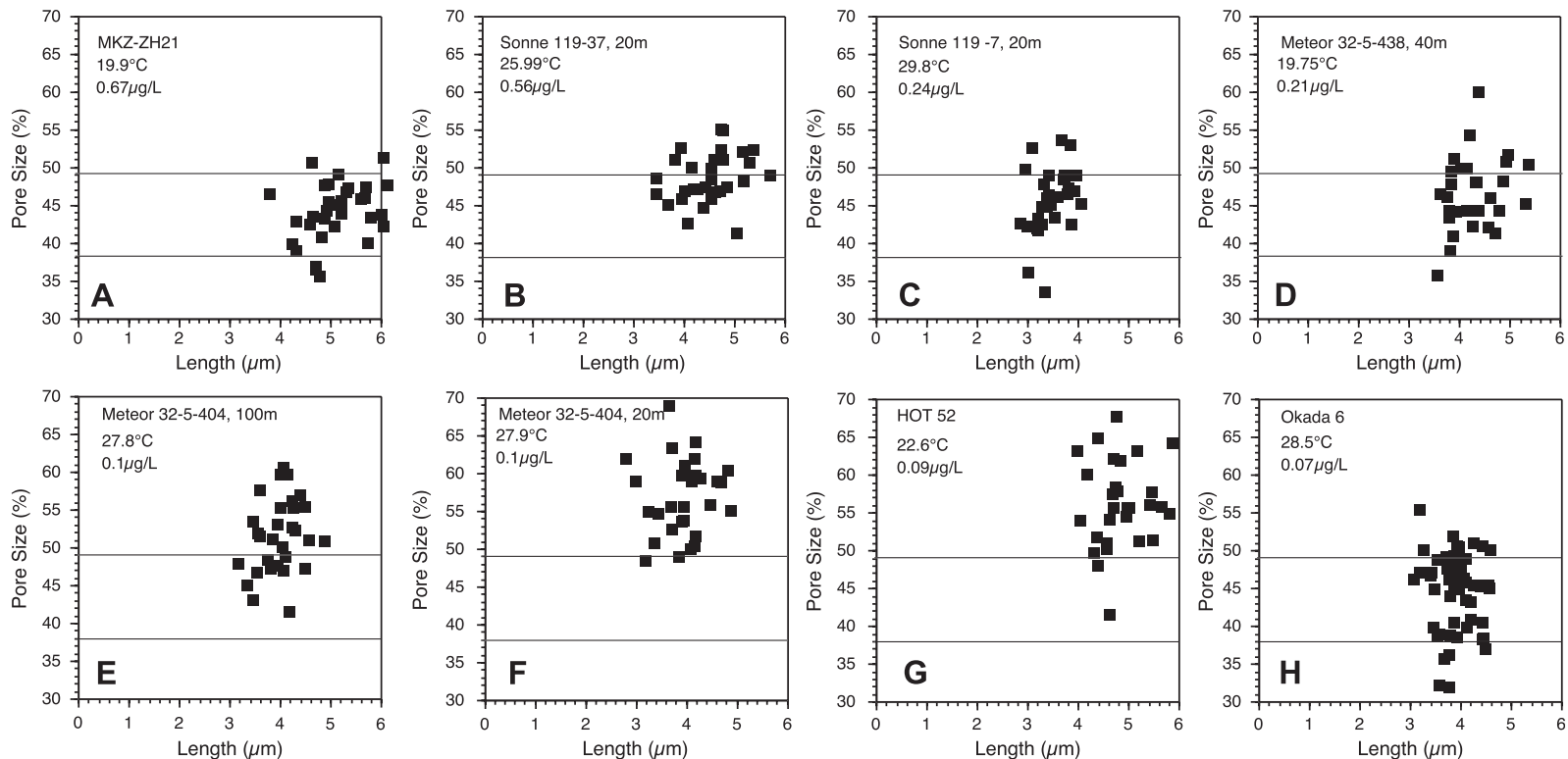

Figure 6. Scatter plots of pore size versus coccolith length of all unimodal GE and GL associations. Lines indicate the mean values reported by Hagino et al. (2000). Each panel represents values for one plankton

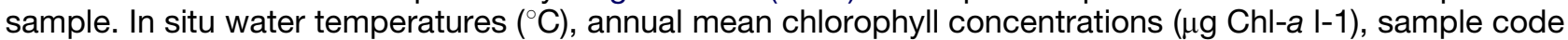
and sampling depth $(\mathrm{m})$ are given in the panels.

Table 2. Comparison of temperature range of the six Gephyrocapsa morphotypes in Holocene sediments and plankton samples, respectively. (Name) Morphotype name. (SST range) Temperature range from Holocene samples based on mean sea surface temperatures. (In-situ temp.) In-situ temperatures at the time and depth of collection of plankton samples.

\begin{tabular}{lll}
\hline Name & SST range $\left({ }^{\circ} \mathrm{C}\right)$ & In-situ temp. $\left({ }^{\circ} \mathrm{C}\right)$ \\
\hline Gephyrocapsa Equatorial & $25-29$ & $27.8-29.8$ \\
Gephyrocapsa Larger & $18-23$ & $13.8-25.8$ \\
Gephyrocapsa Cold & $<21$ & 14.8 \\
Gephyrocapsa Transitional & $19-20$ & 13.8 \\
Gephyrocapsa Oligotrophic & $22-25$ & 22.6 \\
Gephyrocapsa Minute & NN & 23.1 \\
\hline
\end{tabular}

biased by non-biological processes in the sediments. The comparison of ecological ranges of the different morphotypes as reported from Holocene sediments and our plankton data reveal no major differences except for the Gephyrocapsa Transitional morphotype (COD1-3, Table 2).

Furthermore, our data support the findings of Bollmann (1997) that Gephyrocapsa Cold/Transitional and Gephyrocapsa Larger morphotypes are found within similar temperature ranges but in different ecological provinces. The occurrence of unimodal Gephyrocapsa Cold association in plankton samples from the open North Atlantic and the combination of Gephyrocapsa Cold and
Gephyrocapsa Larger morphotypes in the Iberian coasts (Fig. 3L, N-P) suggests different habitats linked to nutrient conditions or other parameters associated with the transition from coastal to open ocean systems.

\section{Conclusion}

Our results confirm the morphological species concept introduced by Kamptner (1943, 1956, 1963) within the genus Gephyrocapsa comprising one group with large bridge angles (G. oceanica var. typica), a group with small bridge angles 
(G. oceanica var. californiensis) and a group with tiny coccoliths (G. aperta). Furthermore, we demonstrate the presence, in plankton samples, of five of six morphotypes reported by Bollmann (1997) from his analysis of Holocene sediment samples (Gephyrocapsa Larger, Gephyrocapsa Equatorial, Gephyrocapsa Cold, Gephyrocapsa Transitional and Gephyrocapsa Minute).

In addition, we show a gradual change in morphological characteristics between Gephyrocapsa Larger and Gephyrocapsa Equatorial along a temperature gradient which could result from the existence of several species with narrow environmental range, eco-phenotypic plasticity within a single species, mixing of the two morphotypes, or a combination of these factors. Testing of these hypotheses requires genetic and culture studies under varying environmental conditions using monoclonal strains from different ocean basins, and is of utmost importance to understanding the diversity of marine plankton and its evolution, and to assessing the impact of future and past environmental change on coccolithophorids.

Finally, our study demonstrates that quantitative analysis of coccolith morphology in the genus Gephyrocapsa and possibly in most extant coccolithophore genera is necessary for addressing key taxonomic, ecological and evolutionary issues.

\section{Methods}

Plankton samples: Sixteen plankton samples were analysed from the Indian, Atlantic and Pacific Oceans (Fig. 2A, Table 1). Water samples were obtained from discrete depths (listed in Table 1) using Niskin and immediately filtered on individual membrane filters. After filtration, samples were dried overnight at approximately $50^{\circ} \mathrm{C}$ and stored in separate containers for further analysis (for additional details see Bollmann et al. (2002)). Information on environmental parameters at the time and depth of collection are provided in Table 1, where available, together with climatic estimates for nutrient concentrations and Chlorophyll-a (Levitus et al. 1998).

Morphometric measurements: Morphometric measurements of plankton samples were carried out according to Bollmann (1997) (Fig. 1 B). A minimum of 30 coccoliths were measured per sample. Isolated coccoliths as well as coccoliths on coccospheres were analysed, when possible. All measurements were collected using a Hitachi S2300 and a Philips XL30 Scanning Electron Microscope (SEM) at a magnification of $8000 \times$.

Because of instrument-related uncertainties when a SEM is used for geometric measurements (for details see ASTM Committee E-4 (1993)), the geometry and accuracy of size measurements in this study were controlled with measurements of $\sim 30$ calibration spheres (width and length) of 2, 5, 7 and $10 \mu \mathrm{m}$ nominal diameter, respectively, before and after each plankton sample measurement series. Correction factors were applied when average sizes for the calibration spheres measured before and after each plankton sample measurement series differed from the nominal sphere sizes. All measurements with an apparent size offset were corrected.

The comparison between measurements of identical calibration spheres (nominal diameter of $1.98 \pm 0.1 \mu \mathrm{m}$ standard error) conducted by Bollmann (1997) and this study, respectively, revealed that all measurements reported by Bollmann (1997) are about $6.5 \%$ too small. The size of calibration spheres measured by Bollmann (1997) was about $1.85 \mu \mathrm{m}$ rather than $1.98 \mu \mathrm{m}$ (Bollmann, unpublished data). This small size offset was assumed to be negligible, as the measurements varied within the given statistical standard deviation of $\pm 0.1 \mu \mathrm{m}$ for this type of calibration sphere. Therefore, the measurements were not corrected for the apparent size offset in Bollmann (1997). However, in this study, all measurements and the resulting morphological boundary values published by Bollmann (1997) were adjusted by a factor of 1.065 in order to avoid a biased sample set. All data are available at http://www.ngdc.noaa.gov/mgg/ geology.

Data treatment: The data treatment was conducted according to Bollmann (1997) using the most important independent morphological characteristics of Gephyrocapsa coccoliths, namely, bridge angle and coccolith length (other measured morphological characteristics where not used because they tend to be correlated with coccolith length). Briefly, the mean value and variance of all morphometric measurements in each assemblage were calculated (Table 1). Box plots were used to compare the variance of coccolith size and bridge angle between single samples (Fig. 4).

Samples were separated into two subsets: one sample subset with low variance in length and bridge angle (unimodal assemblages), and a second sample subset with high variance in length and bridge angle (polymodal assemblages, see Fig. 2C, left and middle panel). Assemblages with standard deviations of less than $16^{\circ}$ for the bridge angle or assemblages with standard deviations of less than $0.7 \mu \mathrm{m}$ for coccolith length were considered to be unimodal. These limits were chosen after visual inspection of frequency histograms of bridge angle and length measurements for each individual plankton sample (example in Fig. 2C, left and middle panels). The remaining assemblages with standard deviations $>16^{\circ}$ for bridge angle or standard deviations $>0.7 \mu \mathrm{m}$ for coccolith length were considered bi- or polymodal. The polymodal assemblages were further subdivided into associations on the basis of the frequency distributions of bridge angle and length. Scatter plots of length versus bridge angle were also used in all cases to support the separations (example in Fig. 2C, right panel). The width of size classes in frequency histograms were $10^{\circ}$ for the bridge angle and $0.4 \mu \mathrm{m}$ for the coccolith length. In addition, a Kruskal-Wallis non parametric variance test (at a 99.9 probability level) of samples (Gephyrocapsa Equatorial Gephyrocapsa Larger ) along a temperature gradient from 20 to $29^{\circ} \mathrm{C}$ revealed that median lengths are separable among this sample set.

\section{Acknowledgements}

Michael Knappertsbusch, Hisatake Okada, Hans R. Thierstein and Ralf Schiebel provided plankton samples. Mara Y. Cortés, Rebecca R. Ghent and Jens $\mathrm{O}$. Herrle made very useful comments on an 
earlier version of the manuscript. The comments of three anonymous reviewers greatly helped to improve the manuscript. This research was funded by the Swiss National Fund Projects: No. 2053-053676: Plankton Ecology and Taxonomy, and JB's Natural Sciences and Engineering Research Council Canada Discovery Grant.

\section{References}

ASTM Committee E-4 (1993) Standard Practice for Calibrating the Magnification of a Scanning Electron Microscope ASTM Designation E 766. ASTM International, West Conshohocken, PA, USA pp 614-617

Bollmann J (1997) Morphology and biogeography of Gephyrocapsa coccoliths in Holocene sediments. Mar Micropaleontol 29: $319-350$

Bollmann J, Cortés MY, Haidar AT, Brabec B, Close A, Hofmann R, Palma S, Tupas L, Thierstein HR (2002) Techniques for quantitative analyses of calcareous marine phytoplankton. Mar Micropaleontol 44: 163-185

Bollmann J, Herrle HO (2007) Morphological variation of Emiliania huxleyi and sea surface salinity. Earth and Planet Sci Lett 255: 273-288

Brand LE (1981) Genetic variability in reproduction rates in marine phytoplankton populations. Evolution 35: $1117-1127$

Brand LE (1982) Genetic variability and spatial patterns of genetic differentiation in the reproductive rates of the marine coccolithophores Emiliania huxleyi and Gephyrocapsa oceanica. Limnol Oceanogr 27: 236-245

Bréhéret JG (1978) Stratigraphie: Formes nouvelles quaternaires et actuelles de la famille des Gephyrocapsaceaem (Coccolithophorides). C R Acad Sc Paris 287: 447-449

Hagino K, Okada H, Matsuoka H (2000) Spatial dynamics of coccolithophore assemblages in the Equatorial WesternCentral Pacific Ocean. Mar Micropaleontol 39: 53-72

Iglesias-Rodríguez MD, Schofield OM, Batley J, Medlin LK, Hayes PK (2006) Intraspecific genetic diversity in the marine coccolithophore Emiliania huxleyi: the use of microsatellite analysis in marine phytoplankton population studies. J Phycol 42: 526-536

Kamptner E (1943) Zur Revision der Coccolithen-Species Pontosphaera huxelyi Lohmann. Anz Akad Wiss Wien, Math Naturw KI 80: 43-49
Kamptner E (1956) Das Kalkskelett von Coccolithus huxleyi (Lohmann) Kamptner und Gephyrocapsa oceanica Kamptner (Coccolithineae). Arch Protistenkd 101: 99-202

Kamptner E (1963) Coccolithineen-Skelettreste aus Tiefseeablagerungen des Pazifischen Ozeans. Ann Naturhistor Mus Wien 66: 139-204

Knappertsbusch M, Cortes MY, Thierstein HR (1997) Morphologic variability of the coccolithophorid Calcidiscus leptoporus in the plankton, surface sediments and from the Early Pleistocene. Mar Micropaleontol 30: 293-317

Levitus S, Boyer T, Burgett R, Conkright M (1998) World Ocean Atlas 1998 (WOA98). Ocean Climate Laboratory, National Oceanographic Data Center Data available at $\langle$ http://ferret.wrc.noaa.gov/las/main.html 〉

McIntyre A, Bé AWH, Roche MB (1970) Modern Pacific coccolithophorida: a paleontological thermometer. N Y Acad Sci Trans 32: $720-730$

Perch-Nielsen K (1985) Cenozoic Calcareous Nannofossils. In Bolli HM, Saunders JB, Perch-Nielsen K (eds) Plankton Stratigraphy. Cambridge University Press, New York, pp $427-554$

Pujos-Lamy A (1976) Emiliania et Gephyrocapsa (Nannoplancton calcaire); Biometrie et interet biostratigraphique dans le Pleistocene superieur marin des Acores. Rev Espan Micropaleontol 9: 69-84

Quinn PS, Cortes MY, Bollmann J (2005) Morphological variation in the deep ocean-dwelling coccolithophore Florisphaera profunda (Haptophyta). Eur J Phycol 40: $123-133$

Saez AG, Probert I, Geisen M, Quinn P, Young JR, Medlin LK (2003) Pseudo-cryptic speciation in coccolithophores. Proc Natl Acad Sci USA 100: 7163-7168

Samtleben C (1980) Die Evolution der CoccolithophoridenGattung Gephyrocapsa nach Befunden im Atlantik. Palaeontol Z 54: $91-127$

Thierstein HR, Young J (2004) Coccolithophores from Cellular Process to Global Impact. Springer, Berlin, p 565

Westbroek P, Brown-Christopher W, van Bleijswijk J, Brownlee C, Brummer GJ, Conte M, Egge J, Fernandez E, Jordan R, Knappertsbusch M, Stefels J, Veldhuis M, van der Wal P, Young J (1993) A model system approach to biological climate forcing; the example of Emiliania huxleyi. Global Planet Change 8: $27-46$

Young JR, Westbroek P (1991) Genotypic variation in the coccolithophorid species Emiliania huxleyi. Mar Micropaleontol 18: $5-23$ 